\title{
Remifentanil alleviates transient cerebral ischemia-induced memory impairment through suppression of apoptotic neuronal cell death in gerbils
}

\author{
Sung-Wook Park ${ }^{1}$, Jae-Woo Yi ${ }^{1}$, Young-Min Kim ${ }^{1}$, Jong-Man Kang ${ }^{1}$, Dong Ok Kim ${ }^{1}$, Mal-Soon Shin ${ }^{2}$, \\ Chang-Ju Kim ${ }^{2}$, Doo Ik Lee ${ }^{3}$, Dong-Hee Kim ${ }^{4}$, and Bong Jae Lee ${ }^{1}$ \\ Departments of ${ }^{1}$ Anesthesiology and Pain Medicine, ${ }^{2}$ Physiology, College of Medicine, Kyung Hee University, Seoul, ${ }^{3}$ Department \\ of Anesthesiology and Pain Medicine, College of Medicine, Inha University, Incheon, ${ }^{4}$ Department of Ophthalmology, College of \\ Medicine, Chungju Hospital, Konkuk University, Chungju, Korea
}

Background: During neurosurgical procedures, patients are often exposed to hypoxic and ischemic brain damage. Cerebral ischemia leads to neuronal cell death and eventually causes neurological impairments. Remifentanil is a new ultra-short acting phenylpiperidine opioid analgesic. In this study, we evaluated remifentanil to determine if it exerts an anti-apoptotic effect in the hippocampal dentate gyrus following transient global ischemia in gerbils.

Methods: Step-down avoidance task, terminal deoxynucleotidyl transferase-mediated dUTP nick end labeling (TUNEL) assay, and immunohistochemical staining for caspase-3 were performed.

Results: The numbers of TUNEL-positive cells and caspase-3-positive cells in the dentate gyrus were increased by ransient global ischemia. Latency in the step-down avoidance task was increased by transient global ischemia. Results revealed that apoptotic cell death in the dentate gyrus was increased significantly following transient global ischemia, resulting in memory impairment. However, treatment with remifentanil suppressed ischemia-induced apoptosis in the dentate gyrus, thereby alleviating the memory impairment that was induced by ischemic cerebral injury.

Conclusions: These results indicate that remifentanil may exert a neuroprotective effect on ischemic brain damage during surgery. (Korean J Anesthesiol 2011; 61: 63-68)

Key Words: Apoptosis, Memory deficit, Remifenanil, Transient cerebral ischemia.

\footnotetext{
Received: August 20, 2010. Revised: January 10, 2011. Accepted: January 20, 2011.

Corresponding author: Bong Jae Lee, M.D., Ph.D., Department of Anesthesiology and Pain Medicine, College of Medicine, Kyung Hee University, 149, Sangil-dong, Gangdong-gu, Seoul 134-890, Korea. Tel: 82-2-440-6192, Fax: 82-2-440-7808, E-mail: lbj8350@naver.com (c) This is an open-access article distributed under the terms of the Creative Commons Attribution Non-Commercial License (http:// creativecommons.org/licenses/by-nc/3.0/), which permits unrestricted non-commercial use, distribution, and reproduction in any medium, provided the original work is properly cited.
} 


\section{Introduction}

During neurosurgical procedures, patients are often exposed to the risk of hypoxic and ischemic brain damage. Therefore, it is important to identify agents that can exert protective effects against brain damage during anesthesia. Remifentanil is a new ultra-short-acting phenylpiperidine opioid analgesic agent that is rapidly metabolized by nonspecific esterases in blood and tissues [1]. Remifentanil has a high clearance due to its small steady-state distribution volume, which results in a rapid decline in blood concentration following termination of infusion when compared to alfentanil. With the exception of being nearly 20 times more potent than alfentanil, remifentanil is pharmacodynamically similar to alfentanil [2]. It has been shown that remifentanil induces a cardioprotective effect on ischemic heart injury through opioid receptors [3]. These protective effects are similar to those associated with ischemic preconditioning, and this effect of remifentanil involves both protein kinase $\mathrm{C}$ activation and mitochondrial $\mathrm{K}_{\mathrm{ATP}}$ channel [4].

Cerebral ischemia results from a reduction in cerebral blood flow due to transient or permanent occlusion of cerebral arteries $[5,6]$. Ischemic insult in the brain, in turn, leads to neuronal cell death, and eventually causes neurological impairment [7-10].

Apoptosis, also known as programmed cell death, is a form of cell death that eliminates dying cells in proliferating or differentiating cell populations [11]. Therefore, apoptosis plays a crucial role in normal development and tissue homeostasis [12]. Conversely, inappropriate or excessive apoptosis has been implicated in several types of neurodegenerative disorders, including ischemia $[13,14]$. Apoptotic cell death can be assessed by terminal deoxynucleotidyl transferase-mediated dUTP nick end labeling (TUNEL) staining, which detects DNA fragmentation $[9,10]$. In addition, another important characteristic of apoptosis is activation of caspase-3, which is a family of cysteinyl proteases and one of the key mediators of apoptosis in mammalian cells $[9,10,15]$.

In this study, we evaluated remifentanil to determine if it exerts an anti-apoptotic effect in the hippocampal dentate gyrus following transient global ischemia. To accomplish this, we evaluated the effects of remifentamil on memory ability and on apoptotic neuronal cell death in the hippocampal dentate gyrus following transient global ischemia in gerbils using a step-down avoidance task, a TUNEL assay, and immunohistochemical staining for caspase-3.

\section{Materials and Methods}

\section{Experimental animals and treatments}

Adult male Mongolian gerbils (11-13 weeks of age) were used in this experiment. Experimental procedures were performed in accordance with the animal care guidelines of the National Institutes of Health (NIH) and the Korean Academy of Medical Sciences. Gerbils were housed under controlled temperature (20 $\pm 2^{\circ} \mathrm{C}$ ) and lighting (07:00 to 19:00 h) conditions, with food and water provided ad libitum.

Gerbils were randomly divided into five groups ( $\mathrm{n}=10$ in each group): a sham-operation group, an ischemia-induction group, an ischemia-induction and $0.02 \mathrm{mg} / \mathrm{kg}$ remifentaniltreated group, an ischemia-induction and $0.2 \mathrm{mg} / \mathrm{kg}$ remifentanil-treated group, and an ischemia-induction and $2 \mathrm{mg} /$ $\mathrm{kg}$ remifentanil-treated group. Remifentanil was obtained from GlaxoSmithKline (GSK) (London, UK). The animals in the remifentanil-treated groups received the respective dose of remifentanil intraperitoneally once a day for 3 consecutive days beginning one day after surgery, while the animals in the sham-operation group received an equivalent dose of saline intraperitoneally once a day for the same duration.

\section{Induction of transient global ischemia}

Transient global ischemia was induced using a surgical procedure based on a previously described experimental method [10]. Occlusion of both common carotid arteries (CCAs) in gerbils induces global ischemia in the brain $[10,16]$. Briefly, the gerbils were anesthetized with $3 \%$ isoflurane in $20 \% \mathrm{O}_{2}-$ $77 \% \mathrm{~N}_{2}$. Following bilateral neck incisions, both CCAs were exposed and occluded with aneurysm clips for $5 \mathrm{~min}$. The clips were then removed to restore cerebral blood flow. The rectal temperature was then maintained at $37 \pm 0.5^{\circ} \mathrm{C}$ using a heating lamp until the gerbil regained consciousness. After recovery, animals were monitored for an additional $2 \mathrm{~h}$ to ensure that hypothermia did not occur. The animals in the sham-operation group were subjected to the same procedure, but the CCAs were not occluded following the neck incisions.

\section{Step-down avoidance task}

Memory ability was evaluated by assessing latency of the step-down avoidance task using a previously described method $[10,17]$. To accomplish this, gerbils were trained to perform the following step-down avoidance task one day after surgery. Gerbils were placed on a $7 \times 25 \mathrm{~cm}$ platform with a $2.5 \mathrm{~cm}$ height and allowed to rest for $2 \mathrm{~min}$. The platform faced a $42 \times$ $25 \mathrm{~cm}$ grid of parallel $0.1 \mathrm{~cm}$-caliber stainless steel bars spaced $1 \mathrm{~cm}$ apart. During the training session, animals received a 0.3 $\mathrm{mA}$ scramble foot-shock for $2 \mathrm{sec}$ immediately upon stepping down. Retention time was then determined 3 days after surgery. The interval of gerbils stepping down and placing all four paws on the grid was defined as the latency time of step-down 
avoidance. When latency was $>180 \mathrm{sec}$, it was recorded as 180 sec.

\section{Tissue preparation}

Gerbils were sacrificed using a previously described method $[10,17]$ immediately after determination of the retention time. Briefly, animals were anesthetized using Zoletil $50^{\circledR}(10 \mathrm{mg} / \mathrm{kg}$, i.p.; Vibac Laboratories, Carros, France), transcardially perfused with $50 \mathrm{mM}$ phosphate-buffered saline (PBS), and then fixed using a freshly prepared solution of $4 \%$ paraformaldehyde in 100 $\mathrm{mM}$ phosphate buffer ( $\mathrm{PB}, \mathrm{pH}$ 7.4). Brains were then dissected and postfixed in the same fixative overnight, after which they were transferred to a $30 \%$ sucrose solution for cryoprotection. Coronal sections that were $40 \mu \mathrm{m}$ thick were then made using a freezing microtome (Leica, Nussloch, Germany).

\section{TUNEL staining}

TUNEL staining was performed to visualize DNA fragmentation using an In Situ Cell Death Detection Kit ${ }^{\circledR}$ (Roche, Mannheim, Germany) according to the manufacturer's protocols $[10,18]$. Briefly, sections were post-fixed in ethanolacetic acid $(2: 1)$ and then rinsed. Next, sections were incubated with proteinase $\mathrm{K}(100 \mu \mathrm{g} / \mathrm{ml})$, rinsed, incubated in $3 \% \mathrm{H}_{2} \mathrm{O}_{2}$, permeabilized with $0.5 \%$ Triton $\mathrm{X}-100$, rinsed again, and then incubated in the TUNEL reaction mixture. Sections were then rinsed and visualized using a Converter-POD with $0.02 \% 3,3$ '-diaminobenzidine (DAB). Sections were then counterstained with Mayer's hematoxylin (DAKO, Glostrup, Denmark) and then mounted onto gelatin-coated slides. Slides were air dried overnight at room temperature, after which coverslips were mounted using Permount ${ }^{\circledR}$.

\section{Caspase-3 immunohistochemistry}

To evaluate caspase-3 expression, caspase-3 immunohistochemistry was performed using a previously described method $[10,18]$. Briefly, sections were drawn from each brain and then incubated overnight with mouse anti-caspase-3 antibody ( $1: 500$; Santa Cruz Biotechnology, Santa Cruz, CA, USA). Sections were then incubated for an additional $1 \mathrm{~h}$ with biotinylated mouse secondary antibody. Bound secondary antibody was then amplified using a Vector Elite ABC kit ${ }^{\circledR}$ (Vector Laboratories, Burlingame, CA, USA). Next, antibody-biotin-avidin-peroxidase complexes were visualized using $0.02 \% \mathrm{DAB}$, after which the sections were mounted onto gelatin-coated slides. Slides were then air dried overnight at room temperature, after coverslips were mounted using Permount ${ }^{\circledR}$.

\section{Data analysis}

The numbers of TUNEL-positive and caspase-3-positive cells in the hippocampal dentate gyrus were counted hemilaterally in every eighth section throughout the entire extent of the dentate gyrus at $400 \times$ magnification. In addition, the area of the granular layer in the dentate gyrus was traced using an ImagePro ${ }^{\circledR}$ Plus image analyzer (Media Cybernetics Inc., Silver Spring, MD, USA) at $40 \times$ magnification. The numbers of TUNELpositive and caspase-3-positive cells were then expressed as cells per $\mathrm{mm}^{2}$ of the cross sectional area of the granular layer in the dentate gyrus. All data were expressed as mean \pm the standard error of the mean (SEM). For comparisons between groups, one-way ANOVA and Duncan's post-hoc test were performed with a $\mathrm{P}<0.05$ being considered as statistically significant.

\section{Results}

\section{Effect of remifentanil on latency during the step- down avoidance task}

Latency time was $4.50 \pm 1.04 \mathrm{sec}$ for the sham-operation group, $0.50 \pm 0.01 \mathrm{sec}$ for the ischemia-induction group, $1.61 \pm 0.31 \mathrm{sec}$ for the ischemia-induction and $0.02 \mathrm{mg} / \mathrm{kg}$ remifentanil-treated group, $3.11 \pm 0.95 \mathrm{sec}$ for the ischemia-induction and $0.2 \mathrm{mg} / \mathrm{kg}$ remifentanil-treated group, and $3.63 \pm 0.50 \mathrm{sec}$ for the ischemiainduction and $2 \mathrm{mg} / \mathrm{kg}$ remifentanil-treated group.

The latency time in the ischemia-induction group was shorter

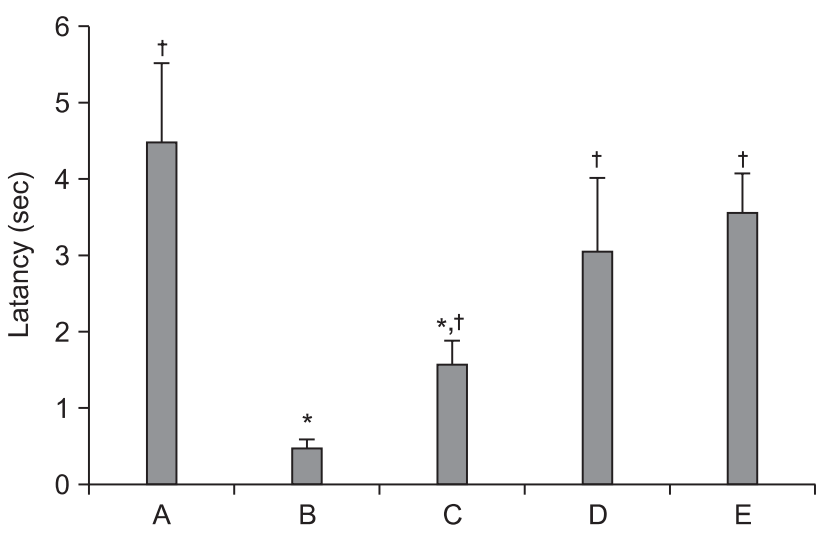

Fig. 1. Effect of remifentanil on latency of a step-down avoidance task following transient global ischemia in gerbils. Results show that remifentanil alleviated ischemia-induced memory impairment. Data shown are the mean \pm SEM. ${ }^{*} \mathrm{P}<0.05$ compared to the shamoperation group. ${ }^{\dagger} \mathrm{P}<0.05$ compared to the ischemia-induction group. (A) Sham-operation group, (B) ischemia-induction group, (C) ischemia-induction and $0.02 \mathrm{mg} / \mathrm{kg}$ remifentanil-treated group, (D) ischemia-induction and $0.2 \mathrm{mg} / \mathrm{kg}$ remifentanil-treated group, (E) ischemia-induction and $2 \mathrm{mg} / \mathrm{kg}$ remifentanil-treated group. 
than that in the sham-operation group (normal), which indicates that treatment with remifentanil significantly increased the latency of ischemic gerbils $(\mathrm{P}<0.05)$. These findings indicate that remifentanil alleviated ischemia-induced memory impairment (Fig. 1).

\section{Effect of remifentanil on the number of TUNEL- positive cells in the dentate gyrus}

Photomicrographs of TUNEL-positive cells in the dentate gyrus are presented in Fig. 2. The number of TUNEL-positive cells was $15.98 \pm 7.61 / \mathrm{mm}^{2}$ in the sham-operation group. This number was increased to $81.10 \pm 14.23 / \mathrm{mm}^{2}$ in the ischemiainduction group, however, it was reduced to $36.26 \pm 14.09 / \mathrm{mm}^{2}$ in the ischemia-induction and $0.02 \mathrm{mg} / \mathrm{kg}$ remifentanil-treated group, to $16.48 \pm 4.96 / \mathrm{mm}^{2}$ in the ischemia-induction and 0.2 $\mathrm{mg} / \mathrm{kg}$ remifentanil-treated group, and to $21.97 \pm 7.98 / \mathrm{mm}^{2}$ in the ischemia-induction and $2 \mathrm{mg} / \mathrm{kg}$ remifentanil-treated group.

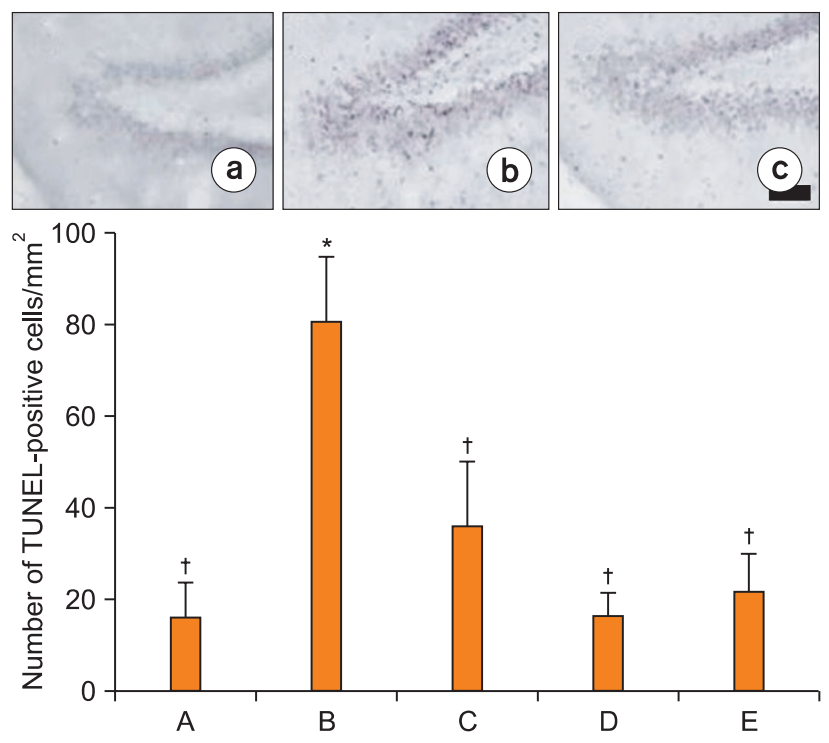

Fig. 2. Effect of remifentanil on DNA fragmentation in the dentate gyrus following transient global ischemia. Results show that induction of ischemia increased apoptotic neuronal cell death in the dentate gyrus and treatment with remifentanil inhibited ischemiainduced apoptotic neuronal cell death. Upper: Photomicrographs of terminal deoxynucleotidyl transferase-mediated dUTP nick end labeling (TUNEL)-positive cells. (a) Sham-operation group, (b) ischemia-induction group, (c) ischemia-induction and $0.2 \mathrm{mg} / \mathrm{kg}$ remifentanil-treated group. Scale bar represents $25 \mu \mathrm{m}$. Lower: mean number of TUNEL-positive cells in each group. Values shown are the mean \pm SEM. $* \mathrm{P}<0.05$ compared to the sham-operation group. ${ }^{\dagger} \mathrm{P}<$ 0.05 compared to the ischemia-induction group. (A) Sham-operation group, (B) ischemia-induction group, (C) ischemia-induction and $0.02 \mathrm{mg} / \mathrm{kg}$ remifentanil-treated group, (D) ischemia-induction and $0.2 \mathrm{mg} / \mathrm{kg}$ remifentanil-treated group, (E) ischemia-induction and 2 $\mathrm{mg} / \mathrm{kg}$ remifentanil-treated group.
These results indicate that ischemic insult enhanced apoptotic neuronal cell death in the dentate gyrus and that treatment with remifentanil significantly suppressed the ischemia-induced apoptotic neuronal cell death (Fig. 2).

\section{Effect of remifentanil on caspase-3 expression in the dentate gyrus}

Photomicrographs of caspase-3-positive cells are shown in Fig. 3. The number of caspase-3-positive cells was $35.40 \pm 10.95$ / $\mathrm{mm}^{2}$ in the sham-operation group. This value was increased to $203.53 \pm 30.90 / \mathrm{mm}^{2}$ in the ischemia-induction group; however, it was reduced to $43.49 \pm 9.70 / \mathrm{mm}^{2}$ in the ischemia-induction and $0.02 \mathrm{mg} / \mathrm{kg}$ remifentanil-treated group, to $19.48 \pm 4.39 / \mathrm{mm}^{2}$ in the ischemia-induction and $0.2 \mathrm{mg} / \mathrm{kg}$ remifentanil-treated group, and to $60.43 \pm 19.09 / \mathrm{mm}^{2}$ in the ischemia-induction and $2 \mathrm{mg} / \mathrm{kg}$ remifentanil-treated group.

These results demonstrate that ischemic insult enhanced caspase- 3 expression in the dentate gyrus and that treatment
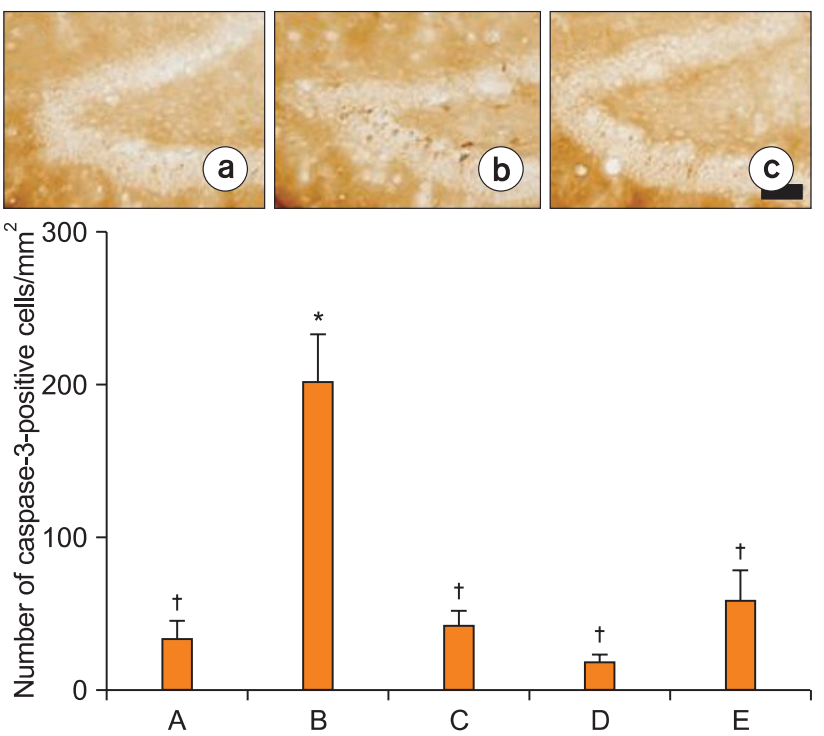

Fig. 3. Effect of remifentanil on caspase-3 expression in the dentate gyrus following transient global ischemia. Results show that induction of ischemia increased caspase- 3 expression in the dentate gyrus and treatment with remifentanil inhibited ischemia-induced increase in caspase-3 expression. Upper: Photomicrographs of caspase-3-positive cells. (a) Sham-operation group, (b) ischemiainduction group, (c) ischemia-induction and $0.2 \mathrm{mg} / \mathrm{kg}$ remifentaniltreated group. Scale bar represents $25 \mu \mathrm{m}$. Lower: number of caspase-3-positive cells in each group. Values shown are the mean \pm SEM. $* \mathrm{P}<0.05$ compared to the sham-operation group. ${ }^{\dagger} \mathrm{P}<0.05$ compared to the ischemia-induction group. (A) Sham-operation group, (B) ischemia-induction group, (C) ischemia-induction and $0.02 \mathrm{mg} / \mathrm{kg}$ remifentanil-treated group, (D) ischemia-induction and $0.2 \mathrm{mg} / \mathrm{kg}$ remifentanil-treated group, (E) ischemia-induction and 2 $\mathrm{mg} / \mathrm{kg}$ remifentanil-treated group. 
with remifentanil significantly suppressed the ischemiainduced increase in caspase-3 expression (Fig. 3).

\section{Discussion}

It has been reported that remifentanil decreases heart rate and mean blood pressure [19]; however, remifentanil is also known to improve haemodynamic stability by suppressing haemodynamic responses to noxious stimuli [20]. In addition, remifentanil has been reported to exert a preconditioning effect that protects ischemic heart injury $[3,4,21]$. Furthermore, dosedependent changes in regional cerebral blood flow have been observed in response to remifentanil infusion in humans [22].

Cerebral ischemia induces deprivation of oxygen and glucose, which results in tissue infarction and neuronal cell death $[5,7]$. Certain regions of the brain, such as the striatum, neocortex, and hippocampus, are highly susceptible to ischemic damage [23], and ischemic injury to the hippocampus is known to induce memory impairment $[9,10,24]$.

In this study, ischemic gerbils were found to have a shorter latency in the step-down avoidance task than shamoperated gerbils. However, treatment of ischemic gerbils with remifentanil significantly increased the latency in the step-down avoidance task. These results demonstrate that remifentanil attenuated ischemia-induced memory impairment in gerbils.

Apoptosis has been implicated in ischemic brain diseases, and the morphological characteristics of apoptotic cell death include cell shrinkage, chromatin condensation, membrane blebbing, and DNA fragmentation $[9,10]$. Caspases, which make up a family of cysteinyl proteases encompassing 14 members, play an essential role in apoptotic cell death by acting as initiators (caspase-2, -8, -9, and -10) and executioners (caspase-3, -6, and -7) [15]. Furthermore, activation of caspases has been implicated in apoptotic neuronal cell death that follows ischemia [7-10]. Specifically, it has been reported that capsase-3 is up-regulated during the early stages of apoptosis following ischemia $[7,9,10]$. Moreover, inhibition of caspases has been reported to induce a neuroprotective effect against brain stroke injury $[25,26]$.

Forebrain ischemia/reperfusion in the gerbil is a well known model for simulating human cerebral ischemia resulting from transient cardiac arrest. In the present results, we evaluated DNA fragmentation by TUNEL staining and capase-3 expression by immunohistochemistry. The results of this study revealed that the numbers of TUNEL-positive and caspase-3positive cells in the dentate gyrus were increased significantly following ischemic attack. This indicates that ischemia leads to apoptotic neuronal cell death in the dentate gyrus. However, treatment with remifentanil decreased the numbers of TUNELpositive and caspase-3-positive cells in the dentate gyrus, which demonstrates that remifentanil suppressed the ischemiainduced apoptotic neuronal cell death in the hippocampal dentate gyrus.

In the present study, induction of global ischemia in gerbils increased apoptotic neuronal cell death in the hippocampus, resulting in memory impairment. Treatment with remifentanil inhibited apoptosis in the hippocampus with amelioration of memory loss. Taken together, the results of this study demonstrate that remifentanil alleviated ischemia-induced memory impairment through the suppression of apoptotic neuronal cell death. Therefore, remifentanil may exert a neuroprotective effect on ischemic brain damage during surgery. However, further studies are needed to evaluate the underlying mechanisms of this neuroprotective effect.

\section{Acknowledgements}

This research was supported by the Research Fund from Kyung Hee University at the year of 2006 (KHU 20061227).

\section{References}

1. Patel SS, Spenser CM. Remifentanil. Drugs 1996; 52: 417-27.

2. Egan TD, Minto CF, Hermann DJ, Barr J, Muir KT, Shafer SL. Remifentanil versus alfentanil: comparative pharmacokinetics and pharmacodynamics in healthy adult male volunteers. Anesthesiology 1996; 84: 821-33.

3. Zhang Y, Irwin MG, Wong TM. Remifentanil preconditioning protects against ischemic injury in the intact rat heart. Anesthesiology 2004; 101: 918-23.

4. Zhang Y, Chen ZW, Girwin M, Wong TM. Remifentanil mimics cardioprotective effect of ischemic preconditioning via protein kinase C activation in open chest of rats. Acta Pharmacol Sin 2005; 26: 546-50.

5. Dirnagl U, Iadecola C, Moskowitz MA. Pathobiology of ischaemic stroke: an integrated view. Trends Neurosci 1999; 22: 391-7.

6. Leker RR, Shohami E. Cerebral ischemia and trauma-different etiologies yet similar mechanisms: neuroprotective opportunities. Brain Res Rev 2002; 39: 55-73.

7. Benchoua A, Guégan C, Couriaud C, Hosseini H, Sampaïo N, Morin $\mathrm{D}$, et al. Specific caspase pathways are activated in the two stages of cerebral infarction. J Neurosci 2001; 21: 7127-34.

8. Love S, Barber R, Wilcock GK. Neuronal death in brain in man. Neuropathol Appl Neurobiol 2000; 26: 55-66.

9. Sim YJ, Kim SS, Kim JY, Shin MS, Kim CJ. Treadmill exercise improves short-term memory by suppressing ischemia-induced apoptosis of neuronal cells in gerbils. Neurosci Lett 2004; 372: 25661.

10. Sim YJ, Kim H, Kim JY, Yoon SJ, Kim SS, Chang HK, et al. Long-term treadmill exercise overcomes ischemia-induced apoptotic neuronal cell death in gerbils. Physiol Behav 2005; 84: 733-8.

11. Kerr JF, Wyllie AH, Currie AR. Apoptosis: a basic biological phenomenon with wide ranging implications in tissue kinetics. $\mathrm{Br} \mathrm{J}$ 
Cancer 1972; 26: 239-57.

12. Woodle ES, Kulkarni S. Programmed cell death. Transplantation 1998; 66: 681-91.

13. Johnson EM Jr, Greenlund LJ, Akins PT, Hsu CY. Neuronal apoptosis: current understanding of molecular mechanisms and potential role in ischemic brain injury. J Neurotrauma 1995; 12: 843-52.

14. Smith CD, Carney JM, Starke-Reed PE, Oliver CN, Stadtman ER, Floyd RA, et al. Excess brain protein oxidation and enzyme dysfunction in normal aging and in Alzheimer disease. Proc Natl Acad Sci U S A 1991; 88: 10540-3.

15. Reed JC. Mechanisms of Apoptosis. Am J Pathol 2000; 157: 1415-30.

16. Liu J, Solway K, Messing RO, Sharp FR. Increased neurogenesis in the dentate gyrus after transient global ischemia in gerbils. J Neurosci 1998; 18: 7768-78.

17. Kim H, Lee SH, Kim SS, Yoo JH, Kim CJ. The influence of maternal treadmill running during pregnancy on short-term memory and hippocampal cell survival in rat pups. Int J Dev Neurosci 2007; 25: 243-9.

18. Jang MH, Shin MC, Jung SB, Lee TH, Bahn GH, Kwon YK, et al. Alcohol and nicotine reduce cell proliferation and enhance apoptosis in dentate gyrus. Neuroreport 2002; 13: 1509-13.

19. Elliott P, O'Hare R, Bill KM, Phillips AS, Gibson FM, Mirakhur RK. Severe cardiovascular depression with remifentanil. Anesth Analg 2000; 91: 58-61.
20. Heijmans JH, Maessen JG, Roekaerts PM. Remifentanil provides better protection against noxious stimuli during cardiac surgery than alfentanil. Eur J Anaesthesiol 2004: 21: 612-8.

21. Kuzume K, Kuzume K, Wolff RA, Chien GL, Van Winkle DM. Remifentanil limits infarct size but attenuates preconditioninginduced infarct limitation. Coron Artery Dis 2004; 15: 449-55.

22. Wagner KJ, Willoch F, Kochs EF, Siessmeier T, Tolle TR, Schwaiger M, et al. Dose-dependent regional cerebral blood flow changes during remifentanil infusion in humans: a positron emission tomography study. Anesthesiology 2001; 94: 732-9.

23. Kindy MS, Bhat AN, Bhat NR. Transient ischemia stimulates glial fibrillary acid protein and vimentin gene expression in the gerbil neocortex, striatum and hippocampus. Brain Res Mol Rrain Res 1992; 13: 199-206.

24. Squire LR, Zola SM. Ischemic brain damage and memory impairment: a commentary. Hippocampus 1996; 6: 546-52.

25. Lee HH, Kim H, Lee MH, Chang HK, Lee TH, Jang MH, et al. Treadmill exercise decreases intrastriatal hemorrhage-induced neuronal cell death via suppression on caspase- 3 expression in rats. Neurosci Lett 2003; 352: 33-6.

26. Cheng Y, Deshmukh M, D'Costa A, Demaro JA, Gidday JM, Shah A, et al. Caspase inhibitor affords neuroprotection with delayed administration in a rat model of neonatal hypoxic-ischemic brain injury. J Clin Invest 1998; 101: 1992-9. 